\title{
THE NONPROFIT HOSPITAL EXEMPTION OF THE NATIONAL LABOR RELATIONS ACT: APPLICATION TO THE UNIVERSITY- OPERATED HOSPITAL IN DUKE UNIVERSITY
}

In Duke University ${ }^{1}$ the National Labor Relations Board (NLRB) faced squarely for the first time the proper application of the nonprofit hospital exemption of section 2(2) of the National Labor Relations Act (NLRA) ${ }^{2}$ in the context of a nonprofit, nonhospital employer operating a medical center and hospital as part of a large university. The Board easily found a basis for jurisdiction over Duke University and its medical center, both of which are intimately connected with Duke Hospital and with one another. Nevertheless, the Board excluded from its jurisdiction all employees who regularly spend over 50 percent of their working time in the Hospital itself. On the other hand, in the sole dissent to the four-member ${ }^{3}$ en banc decision, Member Fanning focused in detail on the meaning of the "hospital exemption" and concluded that, in light of its legislative history, the exemption was not meant to apply to a universityoperated hospital such as Duke Hospital.

While both the majority and dissenting opinions have historical and logical support, both opinions adopted a superficial approach. In the majority opinion, the reader is asked to accept, almost by fiat, the over-simplified reasoning that since Duke Hospital "is a nonprofit hospital operated by a nonprofit university, it appears that, literally, the exclusion . . . applies to it."4 Since, as will be demon-

1. 194 N.L.R.B. No. 31, 78 L.R.R.M. 1547 (1971). In Loyola University Medical Center, 194 N.L.R.B. No. 30, 78 L.R.R.M. 1551 (1971) (decided the same day), the Board dismissed a petition for a bargaining unit of seven electrical maintenance employees who were university employees but who spent over half their time working in a nonprofit hospital operated by Loyola University.

THE FOLLOWING HEREINAFTER CITATIONS WILL BE USED IN THIS NOTE:

Kochery \& Straus, The Nonprofit Hospital and the Union, 9 BUfFalo L. REv. 255 (1960) [hereinafter cited as Kochery \& Straus].

Sherman \& Black, The Labor Board and the Private Nonprofit Employer: A Critical Examination of the Board's Worthy Cause Exemption, 83 HARv. L. REv. 1323 (1970) [hereinafter cited as Sherman \& Black].

2. 29 U.S.C. $\$ 152(2)(1970)$.

3. The vacancy created by Chairman McCulloch's resignation had not yet been filled.

4. 194 N.L.R.B. No. 31, 78 L.R.R.M. at 1549. 
strated in this Note, that conclusion is not nearly so clear-cut, a more comprehensive and analytical approach was to have been expected. This Note will consider the university hospital jurisdictional question against the background of the legislative and judicial history of the section 2(2) exemption with a view toward suggesting the proper application of that exemption.

\section{Background of THE Duke University CASE}

On November 18, 1970, Local 1199D of the National Union of Hospital and Nursing Home Employees ${ }^{5}$ filed a representation petition with the eleventh regional office of the National Labor Relations Board, seeking designation as a bargaining unit of "all of the service and maintenance employees at Duke University Medical Center, a medical teaching center of Duke University." ${ }^{6}$ On the same date the American Federation of State, County and Municipal Employees ${ }^{7}$ petitioned for designation as a bargaining unit of service employees of Duke University in its non-medical facilities. ${ }^{8}$ At the ensuing representation hearing, ${ }^{9}$ Duke University contended that the appropriate bargaining unit was a combined single unit of hospital and campus employees. ${ }^{10}$ While the two petitioners maintained their positions favoring separate units for hospital and campus employees, each intervened in the petition of the other, and both expressed a desire to be

5. The union's full name, as it appeared on the petition, was National Union of Hospital and Nursing Home Employees, RWDSU, AFL-CIO, Local 1199D. 194 N.L.R.B. No. 31, 78 L.R.R.M. at 1547.

6. Id. (Case No. 11-RC-3234). The petition excluded all technical, clerical and professional employees, licensed practical nurses, registered nurses, security officers (guards), administrativc employees and supervisory employees within the meaning of the Act. This petition was administratively dismissed by the Regional Director for the Eleventh Region (possibly for insufficient showing of interest). Local 1199D refiled its petition on December 18, 1970. Case No. 11-RC3251.

7. This petitioner was also an AFL-CIO affiliate. 194 N.L.R.B. No. 31,78 L.R.R.M. at 1547.

8. Id. (Case No. 11-RC-3234). The proposed unit included all cafeteria employees, dining hall employees, maids, housekeepers, janitors, ground crew, utility helpers, counter employees, campus dope shop employees employed at the employer's campus, but excluded skilled and semi-skilled maintenance employees, professional employees, technical employees, office clerical employees, supervisors and guards as defined in the Aet.

9. The cases were consolidated for hearing, which was held in Durham, North Carolina, on January 19, 20, 21 and 22, and on February 3 and 4, 1971.

10. 194 N.L.R.B. No. 31,78 L.R.R.M. at 1547. The estimated number of employees in eaeh separate bargaining unit is approximately 1250 , the broad unit containing something over 2500 . 
on the ballot for any unit eventually found to be appropriate. ${ }^{11} \mathrm{Be}$ cause of the novel and important nature of the jurisdictional question raised under section 2(2) of the National Labor Relations Act, the Regional Director transferred the cases to the Board for decision. ${ }^{12}$ An important question requiring both statutory construction and an exercise of discretion faced the Board: was the section 2(2) nonprofit hospital exemption meant to apply, or did it apply, to the set of circumstances present in Duke? An appropriate starting point, yet one not considered in the majority opinion, is the legislative history of the exemption.

\section{The Legislative Histor ${ }^{13}$}

The original Wagner Act of $1935^{14}$ did not provide any exemption for nonprofit employers. ${ }^{15}$ H.R. 3020, a House bill introduced in 1947, however, contained a broad exemption for nonprofit employers in its proposed section $2(2) .{ }^{16}$ Only a few references to nonprofit

11. Id. Local 1199D amended its petition at the hearing to describe the bargaining unit as follows:

Service employees at Duke Hospital, including its satellites, Duke Pavilion, the Rehabilitation Center, and Child Guidance Center, the storeroom, located in the Anlyan Duke Medical Services Building 6; and including also, clinical assistants in the Medical Diagnostic Clinic; housekeepers and porters, and messengers in Community Health Services; lab assistants in the Department of Surgery; housekeepers and lab assistants in the Department of Anesthesiology; lab assistants in the Department of Pathology; lab assistants in the Department of Pediatrics; orderlies in the Department of Ophthamology; housekeepers, porters and lab assistants in the Department of Micro-Biology and Immunology; animal caretakers in the Department of Anatomy; housekeepers, lab assistants and the head Clerk in the Department of Medicine; housekeepers in the Department of Obstetrics and Gynecology; and animal caretakers in the Department of Veterinarian Medicine. Id., 78 L.R.R.M. at 1547 n.3.

After the Board's decision in Duke University, Local 1199D requested that its name not be included on the ballot submitted to the unit of campus employees.

12. Regional Directors are authorized to transfer representation cases to the Board for decision. 29 C.F.R. \& 101.21(a) (1971).

13. See generally Kochery \& Straus 256-59; Sherman \& Black 1328-37.

14. Act of July 5, 1935, ch. 372, 49 Stat. 449.

15. The relevant portion of section 2 of the Wagner Act of 1935 read as follows:

The term "employer" includes any person acting in the interest of an employer, directly or indirectly, but shall not include the United States, or any State or political subdivision thereof, or any person subject to the Railway Labor Act, as amended from time to time, or any labor organization (other than when acting as an employer), or anyone acting in the capacity of officer or agent of such labor organization. Id. $\S 2(2)$.

16. The relevant portion of the House bill stated:

The term "employer" . . . shall not include . . . any corporation, community chest, fund, or foundation organized and operated exclusively for religious, charitable. scien- 
employers in general were made in the hearings before the House Committee on Education and Labor in February of $1947 . .^{17}$ The chairman of the Board did not discuss the issue in his remarks at the hearings. ${ }^{18}$ The House committee, in its report accompanying the bill, commented on the exemption as follows:

Churches, hospitals, schools, colleges, and societies for the care of the needy are not engaged in "commerce" and certainly not in interstate commerce. These institutions frequently assist local governments in carrying out their essential functions, and for this reason should be subject to exclusive local jurisdiction. The bill therefore excludes from the definition of "employer" institutions that qualify as charities under our tax laws. ${ }^{19}$

At the hearings before the Senate Committee on Labor and Public Welfare, representatives of two influential interest groups offered testimony in favor of an exemption. The American Red Cross appealed for exclusion from the definition of jurisdictional employer on the basis of the organization's charitable nature, federal charter, and its need to pursue its work without danger of interruption by labor strife. ${ }^{20}$ Furthermore, the president of the American Hospital Association requested exemption of hospital employees from the coverage of the Act. ${ }^{21}$ Notwithstanding the testimony favoring an exemption, ${ }^{22}$ the bill was reported out of committee devoid of any exclusion for nonprofit employers, and the report accompanying the bill was silent on this issue. ${ }^{23}$

The Hospital Association lobby, however, was apparently far from ineffective. Senator Tydings offered the amendment exempting nonprofit hospitals, which was eventually incorporated into the NLRA, stating:

tific, literary or educational purposes, or the prevention of cruelty to children or animals, no part of the net earnings of which inures to the benefit of any private shareholder or individual, and no substantial part of the activities of wbich is carrying on propaganda, or otherwise attempting to influence legislation. H.R. 3020, reprinted in H.R. REP. No.

245, 80th Cong., 1st Sess. 47 (1947).

17. See Hearings on Amendments to the National Labor Relations Act Before the House Comm. on Education and Labor, 80th Cong., lst Sess. 742-62, 2700, 2906-07 (1947).

18. Id. at 3163-70. See Sherman \& Black 1329.

19. H.R. REP. No. 245, 80th Cong., lst Sess. 12 (1947).

20. Hearings on Labor Relations Program Before the Senate Comm. on Labor and Publlc Welfare, 80th Cong., 1st Sess. 2057-58 (1947).

21. Id. at 2181-84.

22. Id. The labor unions naturally took a position against an cxemption. Urging NLRA coverage, the president of the United Office and Professional Workers of America argued that those of its members who were employed by social welfare agencies were badly in need of the protections of the Act. Id. at 2260-61.

23. S. REP. No. 105, 80th Cong., Ist Sess. 18, 31 (1947). 
Mr. President, this amendment is designed merely to help a great number of hospitals which are having very difficult times. They are eleemosynary institutions; no profit is involved in their operations, and I understand from the Hospital Association that this amendment would be very helpful in their efforts to serve those who have not the means to pay for hospital service, enable them to keep the doors open and operate the hospitals. Employees of such a hospital should not have to come to the National Labor Relations Board. A charitable institution is way beyond the scope of labor-management relations in which profit is involved . . . .

Senator Taft, the sponsor of the Senate bill, made only one short statement on the subject, indicating his feeling that the Tydings amendment was wholly unnecessary because an identical result would obtain without it through Board discretion. ${ }^{25}$ Nevertheless, the amended bill passed the Senate on May 13.

Three weeks later, in recommending adoption of the Senate version of section 2(2), the House conferees rejected the House's broad exemption for all charitable organizations. ${ }^{26}$ The Conference Committee's expressed reason for the change-that the Board had rarely taken jurisdiction over nonprofit organizations, and then only when their activities were commercial in nature-gave the Conference Report special significance in the Board's determination of its own post- 1947 policies. ${ }^{27}$ The amended bill as reported by the House conferees was passed twice by both the House and Senate--once early in June to enact the measure, and once later the same month to override President Truman's veto.

Commentators have suggested with considerable persuasiveness that the statement in the report of the House conferees as to the Board's policy toward charitable organizations prior to $1947^{28}$ is of dubious credibility. ${ }^{29}$ Specifically, improper reliance seems to have

24. 93 CONG. REC. 4997 (1947).

25. The committee considered this amendment, but did not act on it, because it was felt it was unnecessary. The committee felt that hospitals were not engaged in interstate commerce, and that their business should not be so construed. We rather felt it would open up the question of making further exemptions. Id. (remarks of Senator Taft).

26. H. Conf. ReP. No. 510, 80th Cong., Ist Sess. 32 (1947).

27. The relevant portion of the Conference Report read as follows:

The other nonprofit organizations excluded under the House bill are not specifically excluded in the conference agreement, for only in exceptional circumstances and in connection with purely commercial activities of such organizations have any of the activities of such organizations or of their employees been considered as affecting commerce so as to bring them within the scope of the National Labor Relations Act. Id.

See notes 49-50 infra and accompanying text.

28. See note 27 supra and accompanying text.

29. See, e.g., Sherman \& Black 1331-34. 
been placed on the Board's refusal to assert jurisdiction over a nonprofit employer shortly before the bill was introduced ${ }^{30}$ In fact, the Board had earlier held that hospital activities were "commercial" and stated that the "commerce clause looks to the activities which are carried on, rather than to motives." ${ }^{31}$ Thus, to fully appreciate the meaning of the section 2(2) exemption, consideration of the early decisions of the Board and the courts will be instructive, if not essential.

\section{The EARLy Judicial History}

As early as 1937 the Supreme Court in Associated Press $v$. $N L R B^{32}$ held that an employer's nonprofit status does not exempt that employer from coverage under the NLRA. The Court's decision rested heavily on the fact that the particular employer was formed by, and served, several profit-making newspapers and that the employer extensively used interstate and foreign channels of communication. Two years later the Board asserted jurisdiction over a nonprofit employer publishing religious and medical literature. ${ }^{33}$ Without discussing the commercial nature of the enterprise itself, the opinion focused on the corporation's close relation to interstate commerce and its susceptibility to labor disputes tending to disrupt commerce. Furthermore, in 1942 the Board asserted jurisdiction over the employees of the American Medical Association. ${ }^{34}$ After noting that the Association was a nonprofit scientific and educational organization, the Board concluded that its publishing activities affected interstate commerce with sufficient force to require coverage by the Act. Later the same year, the Board in Polish National Alliance ${ }^{35}$ hinted of a "commerciality" test to be used in dealing with nonprofit employers who otherwise were engaged in interstate commerce. The test focused on the economic effects of the employer's operation rather than the employer's motives. As a nonprofit fraternal benefit corpo-

30. Hyde Park Cooperative Soc'y, 73 N.L.R.B. 1254 (1947). See text accompanying notes 44-45 supra.

31. Central Dispensary \& Emergency Hosp., 44 N.L.R.B. 533, 540 (1942). See notes 37. 38 infra and accompanying text.

32. 301 U.S. 103 (I937).

33. Christian Bd. of Publication, 13 N.L.R.B. 534 (1939), enforced 113 F.2d 678 (8th Cir. 1940).

34. American Medical Ass'n, 39 N.L.R.B. 385 (1942).

35. 42 N.L.R.B. 1375, 1380 (1942), enforced as modified, 136 F.2d 175 (7th Cir. 1943), aff'd, 322 U.S. 643 (1944). Accord, Ass'n Canado-Americaine, 72 N.L.R.B. 520 (1947). 
ration, the Alliance was engaged in a large interstate insurance business for its members. Without discussion, the Board looked past the nonprofit motives to the commercial nature of the enterprise as an overriding consideration. The commerciality test became the standard for almost a decade. ${ }^{36}$

Even though the Board gave a full discussion to the relevance of an employer's nonprofit status two months later in Central Dispensary \& Emergency Hospital, ${ }^{37}$ its opinion adhered to the commerciality factor as determinative. Despite arguments that the hospital's nonprofit status should make it exempt from NLRB jurisdiction, the Board stressed the dominating importance of activities over motives-a fact either overlooked or ignored by the House conferees five years later. ${ }^{38}$ Between the decision in Central Dispensary and the passage of the 1947 Taft-Hartley amendments, the Board asserted jurisdiction in five out of six cases involving nonprofit employers. For example, a corporation operating a cooperative apartment, the shareholders of which were the apartment owners, was found to engage in sufficient commercial activities to be in interstate commerce. ${ }^{39}$ In another case, a nonprofit employer operating a restaurant for employees of the Department of Agriculture was found to be within the category of "employer" because its activities affected commerce. ${ }^{40}$ Jurisdiction was also asserted over a nonprofit trade school, ${ }^{41}$ a nonprofit retail distributor of electricity, ${ }^{42}$ and a nonprofit fraternal benefit society. ${ }^{43}$ In each instance, the motives of the employer were

36. See Sherman \& Black 1331-34.

37. 44 N.L.R.B. 533 (1942). The Board concluded that "[t]he general nature of hospital business is . . . within the meaning of trade or commerce." Id. at 539 . It is interesting to note that hospitals, the setting for the Board's strongest pre-1947 statement of its policy of asserting jurisdiction over nonprofit employers who were engaged in commerce, were the only nonprofit employers excluded from coverage by the Taft-Hartley amendments. See also Central Dispensary \& Emergency Hosp., 50 N.L.R.B. 393 (1943), enforced 145 F.2d 852 (D.C. Cir. 1944), cert. denied, 324 U.S. 847 (1945) (bargaining order).

38. 44 N.L.R.B. at 540. See notes 27, 30-31 supra and accompanying text. The Board also dealt with the hospital's argument that it should not be subject to the Act because it is a charitable institution. The answer given, as valid today as it was then, was that Congress did not intend to exempt charities from the scope of the Act's coverage. Id. at 540-42.

39. Rutland Court Owners, Inc., 44 N.L.R.B. 587 (1942).

40. IVelfare Ass'n of Dep't of Agriculture, 45 N.L.R.B. 285 (1942).

41. Henry Ford Trade School, 58 N.L.R.B. 1535 (1944) (company-funded trade school whose students studied skills needed in the auto industry and repaired tools for the company).

42. Gibson County Elec. Membership Corp., 65 N.L.R.B. 760 (1946).

43. Ass'n Canado-Americaine, 72 N.L.R.B. 52 (1947) (organization of French Catholics having an insurance program similar to that in Polish National Alliance, supra note 35). 
ignored once the Board found that the activities which placed the employer in interstate commerce were typically commercial. The only case involving a nonprofit employer in which jurisdiction was not asserted by the Board during the above period was Hyde Park Cooperative Society. ${ }^{44}$ However, the Board's decision in that case to dismiss the employer petition of a non-stock retail cooperative was based on a finding that its activities did not affect interstate commerce, not on the fact that the motive behind those "local" activities was other than profit-making. While the case has never been cited by the Board as an example of the Board's refusal to assert jurisdiction over nonprofit employers, it was given heavy weight by the House conferees when drafting their report. ${ }^{45}$

The prevailing approach taken by the Board in asserting jurisdiction over employers at the time of enactment of the 1947 section 2(2) exemption emphasized the "commerciality" of activities and transactions rather than the presence or absence of nonprofit motives. In indicating that the Board had rarely asserted jurisdiction over employers who displayed nonprofit purposes, therefore, the legislators of the nonprofit hospital exemption had attributed the Board with a policy which was directly opposite the policy it had actually followed.

\section{Formation of a Worthy CAUSE EXEMPTION}

In the four years following the passage of the Taft-Hartley amendments, the Board continued to assert jurisdiction over nonprofit employers. For example, the Board applied the NLRA to an educational institution and two research foundations connected with it, although the organizations were not operated for profit. ${ }^{46}$ It also extended the Act's jurisdiction to a profit-making radio station operated by a nonprofit educational organization. ${ }^{47}$ Furthermore, in its 1950 decision in General Electric Co. ${ }^{48}$ the Board asserted jurisdiction over a hospital because it was an adjunct established by a commercial employer for the use and benefit of its employees. The real significance of the decision, however, was its reference to the Conference Committee Report-which had indicated that the Board viewed

44. 73 N.L.R.B. 1254 (1947).

45. See notes 27,30 supra and accompanying text.

46. Illinois Inst. of Technology, 81 N.L.R.B. 201 (1949). The Board relied on the fact that the sponsored research projects were of a commercial nature, education being of secondary significance. $I d$. at 202.

47. Port Arthur College, 92 N.L.R.B. 152 (1950).

48. 89 N.L.R.B. 1247 (1950). 
nonprofit organizations generally as not affecting commerce and, therefore, as not being jurisdictional-as being a "fair statement of the Board's policy under the Wagner Act." 49 This seemingly innocuous adoption of a congressional misstatement of the Board's policy was the beginning of a shift in policy toward nonprofit employers which was to prevail for nearly twenty years..$^{50}$

A general "worthy cause" exemption, based upon an examination of employer motives instead of activities, was developed by the Board in Trustees of Columbia University ${ }^{51}$ in 1951. In declining to assert jurisdiction over Columbia University, the Board dismissed a petition for a proposed bargaining unit of library clerical employees, notwithstanding clear evidence that the university fell within prevailing dollar-amount yardsticks for NLRA jurisdiction. ${ }^{52}$ Instead, the Board reasoned that assertion of "jurisdiction over a nonprofit, educational institution where the activities involved are noncommercial in nature and intimately connected with the charitable purposes and educational activities of the institution" would not effectuate the policy of the Act-the elimination of obstructions to the free flow of commerce. ${ }^{53}$ In reaching its conclusion, the Board purported to distinguish previous nonprofit employer cases and recognized the Conference Report as a "guide" from Congress. ${ }^{54}$ For nearly two decades the Board followed this basic policy of examining the purposes of nonprofit employers rather than their impact on commerce.55 Thus, if the employer was a nonprofit organization, the mere fact that its activities had a substantial impact on interstate commerce would no

49. Id. at $1249 \mathrm{n} .4$ (dictum). See note 27 supra and accompanying text. For another case in which the Board asserted jurisdiction over a nonprofit operation created by a commercial employer for its employees, see Olin Indus., Inc., 97 N.L.R.B. 130 (1951).

50. In Sunday School Bd. of the S. Baptist Convention, 92 N.L.R.B. 801 (1950), decided later the same year, the Board split in taking jurisdiction over a nonprofit employer providing advice and literature to Sunday schools. The dissent would have relied on the Conference Committee Report's statement of the Board's policy. Id. at 805.

- 51. 97 N.L.R.B. 424 (1951).

52. For an extensive listing of the then current jurisdictional yardsticks as they applied to Columbia, see id. at 425 n.2.

53. Id. at 427. The policy of the NLRA is found in $\$ 1$ of the Act:

It is declared to be the policy of the United States to eliminate the causes of certain substantial obstructions to the free flow of commerce. . . by encouraging the practice and procedure of collective bargaining .... 29 U.S.C. $\$ 151$ (1970).

54. Trustees of Columbia Univ., 97 N.L.R.B. 424, 427 (1951).

55. See, e.g., California State Auto Ass'n, 170 N.L.R.B. No. 106 (1968); Y.M.C.A. of Portland, 146 N.L.R.B. 20 (1964); Sheltered Workshops, Inc., 126 N.L.R.B. 961 (1960). Cf. Local 33, Hotel \& Restaurant Employees \& Bartenders, 153 N.L.R.B. 392 (1965). 
longer be a sufficient basis for NLRB jurisdiction. ${ }^{56}$

Since Columbia: Universities, Hospitals, and the Developing CONCEPT OF "ANCILLARY RELATIONSHIP"

Duke University was the first NLRB decision to consider the effect of the interaction between a university and a hospital. The case can best be understood after analysis of previous cases involving educational institutions and hospitals separately, and other cases reflecting the interaction of some related, ancillary activity with a university or hospital. Such an analysis will suggest some general conclusions as to the jurisdictional effect of an "ancillary relationship" between two employers who have otherwise different jurisdictional status-a relationship created wherein the activities of one employer are intimately connected with, and ancillary to, those of the other employer. With these goals in mind, the remainder of this Note will be devoted to a review of previous Board cases involving universities and hospitals, a discussion of the probable meaning of the language of the nonprofit hospital exemption itself, and, finally, a consideration of these Board precedents in relation to the Duke University decision.

The impact of the Columbia decision was so pronounced that no significant similar case came before the Board for over a decade. Finally, in the middle 1960's, three cases were decided involving nonprofit university operations. ${ }^{57}$ In each case the standard of Columbia was applied and the nonprofit educational motives of the university were held to overshadow the impact of the university on interstate commerce. Nevertheless, in 1970 the Board in Cornell University $y^{58}$ effected a profound reversal of the Columbia doctrine..$^{5}$ In Cornell, the Board decided that it would better effectuate the purposes of the

56. See Disabled Am. Veterans, Inc., 112 N.L.R.B. 864, 866 (1955), in which an exception was made, however, where the type of activity (manufacture of automobile license identification tags) was eharacteristic of a "highly developed commercial enterprise."

57. Univ. of Miami, 146 N.L.R.B. 1448 (1964) (non-teaching unit of employees engaged in research at special laboratories in an institute located at the university); Massachusetts Inst. of Technology, 152 N.L.R.B. 598 (1965) (university computation center employees); Leland Stanford Jr. Univ., 152 N.L.R.B. 704 (1965) (non-teaching employees in a laboratory housing a linear accelerator). See also Lovelace Foundation for Medical Educ. \& Research, 164 N.L.R.B. 743 (1967). But cf. Wood's Hole Oceanographic Inst., 143 N.L.R.B. 568 (1963) (jurisdiction asserted where research was found to benefit private industry).

58. 183 N.L.R.B. No. 41,74 L.R.R.M. 1269 (1970).

59. For a discussion of Cornell, see 32 U. PITT. L. REv. 416 (1971) and 44 TEMP. L.Q. 410 (1971). 
Act by asserting jurisdiction over two universities-Cornell and Syracuse-whose operations it felt had a substantial impact on commerce. This admittedly complete reversal of policy was based on a recognition that despite their nonprofit status and educational purposes, many universities constitute a sufficient part of interstate commerce to pose a threat of obstruction to the free flow of commerce, a threat which the Act seeks to eliminate. A jurisdictional yardstick of gross annual university revenue (excluding restricted contributions not usable for general expenses) was soon thereafter established at one million dollars. ${ }^{60}$ In the short time since Cornell was decided, petitions for bargaining units at nonprofit schools and universities have been numerous. ${ }^{61}$ When faced with the Duke University factual setting, therefore, the Board had ample precedent for finding jurisdiction over Duke University itself.

The viability of the Board's use of the "ancillary relationship" concept in affecting the jurisdictional status of employers in the university setting is demonstrated by cases involving profit-making employers who provide food services to universities. ${ }^{62}$ In pre-Cornell decisions involving food services, the Board determined such employers to be outside the jurisdiction of the NLRA. ${ }^{63}$ In each instance the Board cited as controlling factors the non-commercial nature of the service and its intimate relationship with the nonprofit educational purposes of the university. However, in the first similar case to reach the Board after the Cornell decision had applied the Act to universities, jurisdiction was asserted over the "ancillary-service" employer ${ }^{64}$ The opinion simply recited that the exemption for universities no longer existed and that the employer's gross sales revenue satisfied the Board's dollar-amount guidelines for NLRA jurisdiction. The impact on Duke University of these cases involving ancillary services to universities is limited, however, in that no case in-

60. 29 C.F.R. $\S 103.1$ (1971), reprinted in 186 N.L.R.B. No. 153, 75 L.R.R.M. 1442 (1970).

61. See, e.g., Corcoran Gallery of Art, 186 N.L.R.B. No. 83, 75 L.R.R.M. 1380 (1970); Boston College, 187 N.L.R.B. No. 16, 75 L.R.R.M. 1532 (1970).

62. For cases involving employers rendering services to hospitals, see notes 72-78 infra and accompanying text.

63. The Prophet Co., 150 N.L.R.B. 1559 (1965); Crotty Bros., 146 N.L.R.B. 755 (1964); Saga Food Serv., Case No. 7-RC-9804, 73 L.R.R.M. 1479 (1970); Saga Food Serv., Case No. 9-RC-61 12, 1965 CCH NLRB REP. T 9,222 (1965). See also Iowa State Memorial Union, 55 L.R.R.M. 1362 (1964) (NLRB Admin. Dec.).

64. I.T.T. Canteen Corp., 187 N.L.R.B. No. 7, 75 L.R.R.M. 1496 (1970). 
volved an ancillary organization which was nonprofit in purpose. They do indicate, nonetheless, that when the "ancillary relationship" concept is applied to universities, the current controlling factor is whether the university is considered to be in interstate commerce and, therefore, within NLRA jurisdiction.

In considering the independent jurisdictional status of hospitals, the Board in 1960 announced in Flatbush General Hospital ${ }^{65}$ that it would not effectuate the policies of the Act to assert jurisdiction over proprietary, profit-making hospitals, even though they had a sufficient inflow of goods to have an impact on commerce as measured by current jurisdictional standards. The Board gave two reasons for the decision-that such hospitals serve primarily local residents, and that they are subject to close regulation by states, including regulation in the field of labor relations since the 1959 amendments to the Act. ${ }^{66}$ In 1967, the Board abandoned this rationale and overruled Flatbush in Butte Medical Properties. ${ }^{67}$ The emphasis in Flatbush on the local nature of proprietary hospital activity was disposed of by noting that many hospital doctors and nurses are imported from outof-state and that proprietary hospitals have a substantial impact on commerce in the aggregate. Further, the Board noted that state regulation of hospitals emphasized inspection and licensing with little attention given to labor relations. A gross revenue standard for NLRA jurisdiction was set at $\$ 250,000$. With this yardstick, the Board has since asserted jurisdiction regularly in cases involving proprietary hospitals and clinics. ${ }^{68}$ In one of these cases, Mayo Clinic, ${ }^{60}$ the Board met and disposed of the pre-Cornell question of whether the employer was primarily engaged in education and research. The latter activities were found to be incidental to the primary purpose of the clinic-the practice of medicine-and insufficient, therefore, to

65. 126 N.L.R.B. 144 (1970).

66. Section 14(c)(2) of the NLRA, 29 U.S.C. \$164(c)(2) (1970), provides that the states may assert jurisdiction "over labor disputes which the Board declines" pursuant to its established jurisdictional yardsticks. Later the same year the fact that the Board had assumed jurisdiction over several disputes involving proprietary hospitals prior to 1959 was held not to have created a prevailing standard within the meaning of section $14(\mathrm{c})(1), 29$ U.S.C. $\$ 164(\mathrm{c})(1)$ (1970), which holds the Board to "standards prevailing upon August 1, 1959." Leedom v. Fitch Sanitarium, Inc., 294 F.2d 251 (D.C. Cir. 1961). Cf. Council 19, American Fed'n of State Employees v. NLRB, 296 F. Supp. 1100 (N.D. Ill. 1968).

67. 168 N.L.R.B. 266 (1967).

68. E.g., Centervilte Clinics, Inc., I81 N.L.R.B. No. 23, 73 L.R.R.M. 1337 (1970); Quain

\& Ramstad Clinic, 173 N.L.R.B. 1185 (1968); Mayo Clinic, 168 N.L.R.B. 557 (1967).

69. 168 N.L.R.B. 557 (1967). 
bar the assertion of NLRA jurisdiction..$^{70}$

In addition to its ability to effect changes in the jurisdictional status of "ancillary" employers operating within the university setting ${ }^{71}$ the "ancillary relationship" concept has had a marked impact on the assertion of Board jurisdiction over employers whose activities are interwoven with the operations of hospitals. While there seems to be no difficulty in asserting jurisdiction over those employers furnishing services to proprietary hospitals, a division appears when the services are being rendered to an exempt nonprofit hospitaI. The cases seem to turn on how intimately the services in question are interwoven with the hospital itself; however, it is often difficult to reconcile the decisions. In cases involving a blood bank, ${ }^{72}$ an employer providing hospital laundry services, ${ }^{73}$ and an employer providing food services ${ }^{74}$ to exempt nonprofit hospitals, the Board declined jurisdiction because of the intimate connection of the employers with the operations of the exempt hospitals. In each of these cases the ancillary "employer" was a corporate entity separate from the hospital itself. On the other hand, employers providing ambulance ${ }^{75}$

70. The Act has been extended to nursing homes regardless of whether or not they are operated for profit. Decided with Butte Medical Properties was University Nursing Home, Inc., 168 N.L.R.B. 263 (1967), in which the Board applied the same principles to open the door to jurisdiction over nursing homes having gross annual revenues in excess of $\$ 100,000$. Since University Nursing the Board has heard and decided to take jurisdiction in many cases involving nursing homes. See, e.g., Visiting Nurses Ass'n, 187 N.L.R.B. No. 88, 76 L.R.R.M. 1096 (1971); Martin Luther Foundation, Inc., 186 N.L.R.B. No. 16, 75 L.R.R.M. 1282 (1970); Rosewood, Inc., 185 N.L.R.B. No. 87, 75 L.R.R.M. 1 I0I (1970); Good Samaritan Hosp., 185 N.L.R.B. No. 86, 75 L.R.R.M. 1103 (1970); Bethany Home for the Aged, 185 N.L.R.B. No. 85, 75 L.R.R.M. 1099 (1970); Drexel Home, Inc., 182 N.L.R.B. No. 151, 74 L.R.R.M. 1232 (1970); 2520 Madison Corp. (Lillian Abrahamson Nursing Home), 174 N.L.R.B. No. 86, 70 L.R.R.M. 1285 (1969); Mar Salle, Inc., 173 N.L.R.B. 429 (1968); Lakeland Convalescent Center, Inc., 173 N.L.R.B. 97 (1968); Somerset Manor, Inc., 170 N.L.R.B. 1647 (1968); Birch Haven Nursing Home, Inc., 170 N.L.R.B. 414 (1968). In the sole case in which jurisdiction was declined, one involving a nonprofit home, the Board was reversed for abuse of discretion. Council 19, American Fed'n of State Employees v. NLRB, 296 F. Supp. 1100, 1104-05 (N.D. Ill. 1968).

71. For cases involving employers rendering services to educational institutions, see notes 63,64 supra and accompanying text.

72. Inter-County Blood Banks, Inc., 165 N.L.R.B. 252 (1967) (reversing the Regional Director's decision in Case No. 29-RC-574, 63 L.R.R.M. 1404 (1966)).

73. United Hosp. Servs., Inc., 172 N.L.R.B. No. 168, 69 L.R.R.M. 1046 (1968).

74. Horn \& Hardart Co., 154 N.L.R.B. 1368, 1370 (1965), where the Board declined to assert jurisdiction because "the food service operations performed by the employer under its contract with the Hospital [were] incidental to and intimately connected with the patient care and medical education purposes of the Hospital."

75. Bob's Ambulance Serv., 178 N.L.R.B. No. 1, 71 L.R.R.M. 1587 (1969). 
and warehousing ${ }^{76}$ service to exempt hospitals were found to be within the Board's jurisdiction. It is easy to accept this result since neither of these latter services involves in-hospital patient care nor is an activity which a hospital customarily performs for itself. The most difficult cases to reconcile are decisions in which the Board has asserted jurisdiction over employers providing housekeeping ${ }^{77}$ and cleaning and maintenance services. ${ }^{78}$ These services are related to patient care and are traditionally performed by hospitals themselves, yet the Board takes jurisdiction while declining the same in the case of laundry services. Consequently, whenever there exists an ancillary relationship in which an exempt hospital occupies the role of dominant employer, the only confident position which can be taken with regard to the net jurisdictional effect of the relationship is that in some cases the coverage of the Act will be denied to ancillary employers who are otherwise jurisdictional.

Closer to the factual setting in Duke University are cases in which nonprofit hospitals, arguably excluded by section 2(2), have assumed an ancillary role in relation to profit-making employers engaged in interstate commerce and have consistently been brought within the Act's coverage. Jurisdiction has thus been asserted over hospitals established to serve employees of commercial businesses such as mining ${ }^{79}$ manufacturing, ${ }^{80}$ and a hospital associated with a profit-making clinic pharmacy. ${ }^{81}$ In another case, jurisdiction was asserted where a hospital was found to affect the national defense. ${ }^{82}$ The significance of employer activity interrelationship was similarly demonstrated in a recent case where two "convalescent units" to which the Act would normally apply were left without its protection because they were found to be too closely associated with a statutorily excluded hospital. ${ }^{83}$ All of the above cases where NLRA jurisdiction was asserted possess one common feature: the dominating employer in the "ancillary relationship" was a profit-making operation. If Duke University

76. Southern Permanente Serv., Inc., 172 N.L.R.B. No. 148, 68 L.R.R.M. 1504 (1968).

77. Richmond of New Jersey, Inc., 168 N.L.R.B. 820 (1967).

78. Bay Ran Maintenance Corp., 161 N.L.R.B. 820 (1966). See Chimney \& Furnace Vacuum Cleaning Corp., 169 N.L.R.B. 994 (1968).

79. Miami Inspiration Hosp., Inc., 175 N.L.R.B. 636 (1969); Kennecott Copper Corp., 99

N.L.R.B. 748 (1952).

80. General Elec. Co. (Kadlec Hosp.), 89 N.L.R.B. 1247 (1950).

81. Parkvue Medical Center, 183 N.L.R.B. No. 65, 74 L.R.R.M. 1689 (1970).

82. Hospital Hato Tejas, Inc., 111 N.L.R.B. 155 (1955).

83. Sierra Hosp. Foundation, 181 N.L.R.B. No. 143, 73 L.R.R.M. 1541 (1970). See also Wesleyan Foundation, 171 N.L.R.B. No. 22, 68 L.R.R.M. 1035 (1968). 
were a profit-making enterprise, therefore, a strong line of precedents would suggest NLRA coverage of the hospital. Exclusion of Duke Hospital from the Act's jurisdiction in the Duke University decision, however, indicates a choice by the Board not to extend the "ancillary relationship" concept to assert jurisdiction over hospitals dominated by nonprofit employers, despite the fact that the Board has extended its jurisdictional arm to hospitals connected with dominant profitmaking employers, and even though both types of employers have been found to be engaged in interstate commerce and independently subject to the Act's jurisdiction.

\section{The Meaning of the Hospital Exemption and its Application to Duke Hospital}

The nonprofit hospital exemption is conspicuously absent from the definition of "employer" in the Labor-Management Reporting and Disclosure Act of $1959,{ }^{84}$ the Welfare and Pension Plans Disclosure Act ${ }^{85}$ Title VII of the Civil Rights Act of $1964,{ }^{86}$ and the Fair Labor Standards Act of $1938,{ }^{87}$ in which hospital employers employed by a state or its subdivision are specifically included. In fact, the Taft-Hartley amendment is the sole piece of federal labor legislation to exempt nonprofit hospitals from its coverage. The National Labor Relations Act regulates relationships between "employers" and "employees"; "employee" is defined to exclude persons who do not work for an "employer." 88 Thus, the source for exclusion of certain hospitals and their employees is the following language of the Taft-Hartley amendment:

The term "employer" . . . shall not include . . . any corporation or association operating a hospital, if no part of the net earnings inures to the bcnefit of

84. 29 U.S.C. $\S 402(1970)$.

85. Id. § 301 .

86. 42 U.S.C. $\S 2000 \mathrm{e}(1970)$.

87. Fair Labor Standards Act § 3(d)(1), 29 U.S.C. § 203(d)(1) (1970), amending 29 U.S.C. $\S 203$ (d) (1964). The Act was amended in 1966 to extend minimum wage coverage to nonprofessional employees at state schools and hospitals. The constitutionality of the amendment was upheld in Maryland v. Wirtz, 392 U.S. 183, $193-99$ (1968):

We think the District Court was correct in declining to decide in the abstract and in general, whether schools and hospitals have employees engaged in commerce or production. Such institutions, as a whole, obviously purchase a vast range of out-of-state commodities. These are put to a wide variety of uses, presumably ranging from physical incorporation of building materials into hospital and school structures, to over-thecounter sale for cash to patients, visitors, students, and teachers. Id. at 201.

88. NLRA § 2(3), 29 U.S.C. § 152(3) (1970). 
any private shareholder or individual $\ldots{ }^{89}$

Even after twenty-five years, the exact meaning of this language remains something of a mystery. The Board itself has admitted that it is "difficult to define" what is or is not an exempt hospital. ${ }^{90}$ From the quoted language it can be seen that three questions must be answered affirmatively in determining whether the exemption applies: (1) whether the facility is a "hospital"; (2) whether the organization operating the facility is devoid of private shareholders and individual owners; and (3) whether no part of the net earnings inures to the benefit of such shareholders or individuals.

Most basic of the three questions is whether or not the facility being operated is a "hospital." Although neither the statute nor a single Board decision offers an express definition, the meaning of the term can be divined from several Board decisions. One consideration frequently employed is whether the facility is classified as a "hospital" by its license, organizational accreditation, articles of incorporation, or charter. ${ }^{91}$ In addition, something more than beds and nursing care is required in order to qualify for exempt status. ${ }^{92}$ Furthermore, the hospital exemption has been denied to a "sub-acute" facility, which provided services ranging from intensive care to custodial nursing services but lacked a permanent staff of doctors, ${ }^{93}$ and to a facility offering extended care. ${ }^{94}$ Since the Board has provided only hints of the exemption's scope instead of an express definition, the suggestion arises that the Board assumes that the congressional meaning is so obvious that it deserves no in-depth discussion. Nevertheless, the Board's decisions seem to indicate that in order to qualify as an exempt hospital, the facility must provide a wide range of facilities and services for the treatment of the ill, including inpatient care, a staff of doctors, laboratory facilities, and other "acute" services. By attaining these earmarks, in addition to licensing by state law and accreditation from a hospital association, qualification for the exemption is possible.

89. Id. $§ 152(2)$.

90. Children's Village, Inc., 186 N.L.R.B. No. 137, 75 L.R.R.M. 1476 (1970). In an carlier case involving the same employer, the Board had declined to give an advisory opinion as to the exempt status of the institution. I80 N.L.R.B. No. 169, 73 L.R.R.M. 1250 (1970).

91. Rosewood, Inc., 185 N.L.R.B. No. 87, 75 L.R.R.M. 1101 (I970).

92. See Good Samaritan Hosp., 185 N.L.R.B. No. 86, 75 L.R.R.M. 1103 (1970) (NLRA jurisdiction asserted over 215-bed nursing home); Bethany Home for the Aged, 185 N.L.R.B. No. 85, 75 L.R.R.M. 1099 (1970) (NLRA jurisdiction asserted over 212-bed nursing home).

93. Martin Luther Foundation, Inc., 186 N.L.R.B. No. 16, 75 L.R.R.M. 1282 (1970).

94. Rosewood, Inc., 185 N.L.R.B. No. 87, 75 L.R.R.M. 1101 (1970). 
Even if the facility qualifies as a "hospital" by virtue of its activities, the applicability of the nonprofit hospital exemption depends, secondly, on whether or not the corporation or association which operates the facility is devoid of private shareholders. Again, the Board has shunned detail when discussing ownership of hospitals. Whether or not the entity operating the hospital is organized under state law as a corporation, nonprofit or otherwise, has had a substantial effect on the determination of this ownership issue. Although other organizational forms may also be found to include individuals standing in the place of shareholders, the Board's usual approach has been a conclusionary one as to the presence or absence of proprietary features. ${ }^{95}$

Even if the organization operating the hospital is found to have private shareholders, the nonprofit hospital exemption will apply if "no part of the net earnings inures" to their benefit ${ }^{96}$ It is not clear whether this language means that earnings must actually be distributed to the owners, or whether it is sufficient for jurisdictional purposes that the organization is set up such that if earnings were distributed, a part of them would have to go to shareholders. It is equally unclear whether the earnings in question must be those of the hospital alone, or the earnings of the operating "corporation or association," which may also have other activities. Neither of the above questions has been answered directly; however, as long as the corporation is structured to give shareholders the potential to share the earnings from any aspect of its business, the exemption would probably not apply.

By these standards, Duke Hospital, taken as an isolated entity, is a clear example of that class of institutions which the Act requires to be exempt from its coverage. It provides the "acute" care over a wide range which separates it from mere convalescent homes. Its earnings, if any, inure to the benefit of no shareholder or individual. Indeed, there are no shareholders of the nonprofit corporation creating Duke University, from which Duke Hospital has no separate legal existence. ${ }^{97}$ Thus, notwithstanding the Board's prior failure to articu-

95. For cases involving the presence of proprietary organizations, see, e.g., Butte Medical Properties, 168 N.L.R.B. 266 (1967); University Nursing Home, Inc., 168 N.L.R.B. 263 (1967); Flatbush General Hosp., 126 N.L.R.B. 144, 45 L.R.R.M. 1286 (1960). For nonprofit institutions, see, e.g., Good Samaritan Hosp., 185 N.L.R.B. No. 86, 75 L.R.R.M. 1103 (1970).

96. See note 89 supra and accompanying text.

97. Duke Univ., 194 N.L.R.B. No. 31, 78 L.R.R.M. 1547, 1549 (1971). Duke University is organized under the Non-Profit Corporation Act of North Carolina, N.C. GEN. STAT. \&s 55A-1 to -89.1 (Supp. 1971). 
late exact standards, it is not surprising that Duke Hospital was found within that class of institutions at which the exemption is aimed. Without looking further, that fact should clearly dictate against the Board's assertion of jurisdiction over a university hospital such as Duke Hospital.

Once the nonprofit hospital exemption is found, however, a fourth inquiry is necessary to determine its scope-whether the exclusion applies to the association or corporation operating the hospital, or to the hospital itself. It seems clear from the relevant text of the exemp$\operatorname{tion}^{98}$ that it does apply, at least on its face, to the operating corporation or association. Carrying that construction to its logical conclusion, however, would result in many exclusions from coverage of operations much larger than the hospital. Consequently, the Board in Duke University continued its practice of limiting the scope of the exemption to the hospital entity itself once it has found the exemption applicable.

The narrow scope given the nonprofit hospital exemption by the Board is consistent with the Board's policy of reading broadly the jurisdictional language of the NLRA, while construing exemptions narrowly. The Board has, for example, asserted jurisdiction over what it considered to be an exempt nonprofit hospital on the theory that the hospital was a "person engaged in commerce" within the meaning of the secondary boycott provision of section $8(b)(4) .^{99}$ Furthermore, in several cases the relationship of an otherwise jurisdictional operation to an otherwise exempt operation has been used as a means for asserting or declining jurisdiction jointly over both enterprises. ${ }^{100}$ In each case, the basis for the decision has been whether or not the policies of the Act would be effectuated. Adherence to these policies creates a propensity in the Board to become involved in a broadening range of circumstances, producing unpredictable results.

\section{The Ancillary Relationship and Proper-Employer IsSues: Two RECENT DECISIONS}

Any attempt to apply the section $2(2)$ exemption in a setting such

98. See note 89 supra and accompanying text.

99. Local 3, IBEW, 128 N.L.R.B. 566 (1960). See also Local 2669, United Bhd. of Carpenters and Joiners, 173 N.L.R.B. 1232 (1968). Cf. NLRB Gen. Counsel Admin. Ruling No. SR1629, 49 L.R.R.M. 1306 (1961). Prior to 1959, the Board applied the same jurisdictional standards in alI unfair labor practice cases and representation proceedings. San Diego Bldg. Trades Council v. Garmon, 353 U.S. 26, 28 n.4 (1957); see C.A. Braukman, 94 N.L.R.B. 1609 (1951).

100. See notes $72-78$ supra and accompanying text. 
as Duke University must face the concept of "ancillary relationship" and the need for ascertaining the proper jurisdictional employer. Two recent decisions, involving nonprofit hospitals that were related to the operations of other employers, have a significant bearing on these concepts and, consequently, on how Duke might have been decided. In Sierra Hospital Foundation ${ }^{101}$ jurisdiction was declined over a hospital and two "sub-acute"102 convalescent units. In a firm application of the ancillary relationship concept, the Board concluded that the convalescent units, offering a total of 99 beds, were so closely related to the exempt hospital as to be inseparable for purposes of NLRA jurisdiction. In reaching this result, the Board found that the entire operation was conducted, both administratively and functionally, as a single entity, all three facilities being governed by one set of bylaws and administered by one board of trustees. A second basis for the decision was the fact that the hospital services rendered in the two convalescent units were "closely and intimately related to, and in some situations . . . inseparable from, the hospital services."103

Less than three months later, the Board in Parkvue Medical Center ${ }^{104}$ asserted jurisdiction over an otherwise exempt hospital which was operated in conjunction with a profit-making medical center and pharmacy. The hospital's charter contained a provision, present since its incorporation in 1959 under the nonprofit corporation laws of Michigan, providing that no part of its net earnings could inure to the benefit of any person, and that upon dissolution, its trustees must distribute its assets to another nonprofit institution of like character. Notwithstanding its nonprofit purpose, the hospital was located in a building which also accommodated Parkvue Medical Center and the Parkvue Pharmacy, both profit-making enterprises. The building proprietors owned the entire medical center, possessed a one-half interest in the pharmacy, and served as trustees and directors of the hospital. In determining that all of these operations were "interrelated parts of an integrated operation" and, therefore, constituted a single employer, the Board found that the hospital "[had] no true viability apart from the Center upon which it must rely for its complete and effective operation" and that the three together were

101. 181 N.L.R.B. No. 143, 73 L.R.R.M. 1541 (1970).

102. See Martin Luther Foundation, Inc., 186 N.L.R.B. No. 16, 75 L.R.R.M. 1282 (1970); note 93 supra and accompanying text.

103. Sierra Hosp. Foundation, 181 N.L.R.B. No. 143, 73 L.R.R.M. 1541 (1970).

104. 183 N.L.R.B. No. 65,74 L.R.R.M. 1689 (1970). 
"operated primarily for business purposes." 105 The Board concluded that the limitations of the section 2(2) exemption had been exceeded, citing General Electric Co. ${ }^{106}$ Kennecott Copper, ${ }^{107}$ and Miami Inspiration Hospital. ${ }^{108}$

While neither Sierra nor Parkvue is dispositive of the legal issues presented in Duke University, both cases are instructive for understanding the Board's approach in the Duke decision. Of the two cases, Parkvue is more similar to the Duke setting and would appear to present a controlling analogy were it not for the finding that the Parkvue Hospital relied completely on two profit-making enterprises for its existence in a structurally combined operation. Duke Hospital is very likely capable of a viable existence apart from the University itself, and this fact ostensibly provides a potential basis of distinction between the Duke University and Parkvue cases. Yet the degree of integration of Duke Hospital with the non-exempt educational facility-Duke University-is sufficient to support a finding that it has no separable existence. Its doctors and paramedical staff are, in many instances, concurrently involved in routine patient care, medical research and medical education, the last two being proper functions of a university. To separate the latter functions and associated personnel from the hospital proper would likely cause serious damage to its role as a hospital.

A second potential basis of distinction between the Duke University and Parkvue cases lies in the fact that in viewing the university and hospital in Duke University as an integrated operation, the overall purpose emerges as educational and nonprofit, as opposed to the business-for-profit purpose of the integrated network in Parkvue. This basis for distinction, however, is diminished by the fact that the Board has practically abandoned its commerciality 100 and employer purpose ${ }^{10}$ tests, and it is difficult to understand why they were apparently raised again in Parkvue. Furthermore, an additional factor which could have been used to bring the factual setting in Duke University even closer to that found in Parkvue-the existence of a large Private Diagnostic Clinic serving outpatients for profit in the main hospital building-was not even mentioned in the Duke

\footnotetext{
105. Id., 74 L.R.R.M. at 1692.

106. 89 N.L.R.B. 1247 (1950).

107. 99 N.L.R.B. 748 (1952).

108. 175 N.L.R.B. 636 (1969).

109. See notes 35-37 supra and accompanying text.

110. See notes 51-56 supra and accompanying text.
} 
opinion. As a result, although Parkvue can be distinguished from Duke on the ground that Parkvue Hospital was operating in conjunction with a jurisdictional, profit-making enterprise whereas Duke Hospital was operating as a part of a jurisdictional, nonprofit educational institution, this basis for distinction would disappear if Parkvue could be read broadly to hold that a nonprofit hospital operated as an inseparable part of any jurisdictional employer will not be exempted from the Act.

Duke University evolved in the wake of these two decisions and in the historical setting which has been detailed in the preceding sections. It provided the opportunity for clarification of the proper employer and ancillary relationship issues which will arise inevitably in the setting of an otherwise exempt nonprofit hospital attached to a jurisdictional nonprofit university. Yet what the Board chose to do with the opportunity is far from satisfying.

\section{The Decision in Duke University}

The possibility that the Board might not assert jurisdiction over Duke Hospital was not considered until late in the representation hearing, and even then it was raised only by the hearing officer. ${ }^{111}$ Unlike the employer in Mayo Clinic, ${ }^{112}$ where the parties urged the Board to assert jurisdiction (which it did without attempting to deal with the section 2(2) problem), the employer in Duke University took no position as to whether the hospital was covered by the NLRA. Local 1199D sought to avoid the problem entirely by arguing that there was only one applicable employer, Duke University, a position which found considerable support in the Board's dissenting opinion. In support of this position, the petitioning union emphasized several aspects of Duke University's organization and purpose which it felt should be decisive. First, the University, including the hospital, medical center, and medical school, was run by one Board of Directors through an interlocking hierarchy of department heads. Furthermore, although the hospital ${ }^{113}$ was budgeted as a self-supporting operation, operating deficits had been absorbed by the University's general fund. ${ }^{114}$ Finally, all hospital wages and salaries were paid by the

111. At the representation hearing, the parties stipulated that the University as a whole was an employer within the meaning of the Act.

112. 168 N.L.R.B. 557 (1967); see note 69 supra and accompanying text.

113. Three hospitals, including those at Sea Level and Highlands, North Carolina, are involved in the unit determination.

114. This fact was omitted from the discussion in the majority opinion in Duke University. 
university, as were other expenditures for the hospital, based on annual budgets. In short, it was urged by the petitioner that the type of university-hospital involved here was sui generis in nature and should be treated as a university, not as a university and a hospital. ${ }^{115}$

The majority in Duke University, in its short consideration of the jurisdictional question, began its reasoning with the assumption that the exemption of section 2(2) applies to "hospitals operated by corporations or associations"116 not for profit, thereby deciding without comment that hospitals themselves rather than the organizations operating the hospitals are excluded. Thus, Duke Hospital was found to be within the literal meaning of the exemption. Next, the Board practically ignored the ancillary relationship problem by simply concluding that the section 2(2) exclusion related to hospital functions, and thus the Board was "prohibited by the statute from asserting jurisdiction over the hospital functions of Duke University." 117 No attempt was made to ascertain the true meaning of the exemption, assuming one can ever be determined; nor were prior Board decisions discussed. ${ }^{118}$

Dissenting Board Member Fanning, on the other hand, relied on the proposition that there was only one employer-the university-and concluded that all Duke University employees, including its hospital employees, were within NLRA jurisdiction. In reaching this conclusion, the dissenting Board member applied to this overall university employer the language of section 2(2) as enlightened by its meager legislative history. His reasoning was that either (1) Duke University, the employer, operated a university and incidentally a hospital-in which case it is an employer within the meaning of the Act and all its employees were covered; or (2) because it operated a nonprofit hospital, it was not an employer at all within the meaning

115. Nor was the position of Local 1199D, that the hospital service employees in the Hcspital and Medical Center constituted an appropriate bargaining unit, inconsistent with its jurisdictional theory, since section $9(\mathrm{~b})$ of the Act ccmmands that for a given employer the Board shall decide which unit assures emplcyees the fullest freedcm for exercising their guaranteed rights. NLRA § 9(b), 29 U.S.C. $§ 159$ (b) (1970).

116. 194 N.L.R.B. No. 31,78 L.R.R.M. 1547, 1549 (1971).

117. Id.

118. The Board also mentioned Loyola Univ., 194 N.L.R.B. No. 30, 78 L.R.R.M. 1551 (1971) (which cited without discussion Sierra Hcsp. Fcundation, 181 N.L.R.B. No. 143, 73 L.R.R.M. 1541 (1970); The Wesleyan Foundation, 171 N.L.R.B. No. 22, 68 L.R.R.M. 1035 (1968); Lovelace Fcundaticn for Medical Educ. and Research, 165 N.L.R.B. 743 (1967); and United Hosp. Servs., Inc., 172 N.L.R.B. Nc. 188, 69 L.R.R.M. 1046 (1968)). 194 N.L.R.B. No. 31, 78 L.R.R.M. at 1549. 
of the Act and none of its employees were covered. To support his conclusion that all Duke employees must be covered, he noted from the legislative history that Duke Hospital did not fit the class of struggling, nonprofit hospitals which he felt Congress intended to protect by the exemption. ${ }^{119}$

The flaw in the logic of the dissenting opinion lies in its premise that there could be only one employer-the university - to which the jurisdictional language of the statute would apply. Not a single case was, or can be, cited in direct support of the dissenting position. ${ }^{120}$ On the other hand, several Board decisions dealing with potentially exempt hospitals have openly discarded reliance on corporate structure and have examined instead the relationships between, and integration of, functionally distinct units that are controlled by the same corporate "employer."121

Neither the majority nor dissenting approach is intellectually or historically satisfying. The majority clearly departs from the literal language of the exemption. The dissenter relies too heavily on an attenuated meaning of legislative history, which, if it would have any effect on the construction of the exemption, weighs more against his position than in favor of it. The most logical approch would have been to begin with the assumption that the exemption was aimed at the hospital itself. A reasonable explanation, perhaps one which even Member Fanning could accept, would seem to be that the sparse legislative history of the exemption indicates that it was intended to benefit hospitals only-not the larger operating organizations. The terms "corporation or association" were undoubtedly inserted to accomodate the exemption's application to a business entity, since "hospital" alone might mean only the physical facility itself, devoid of power to employ workers.

A major shortcoming of the Duke University decision was the Board's failure to confront the question of the jurisdictional effect of the ancillary relationship between an appurtenant hospital and its dominant employer, a university. The relationship of an exempt hospital to an employer over which the Board asserts jurisdiction has

119. See note 24 supra and accompanying text.

120. Siemons Mailing Serv., 122 N.L.R.B. 81 (1958), was cited in this vein, but it merely stands for the proposition that once part of an employer's operation is found to satisfy jurisdictional standards (dollar amount), the entire operation is covered.

121. See, e.g., Parkvue Medical Center, 183 N.L.R.B. No. 65, 74 L.R.R.M. 1689 (1970); Miami Inspiration Hosp., Inc., 175 N.L.R.B. 636 (1969). 
never been without significance. It is in this context that the importance of Duke is highlighted. While in Parkvue the Board took jurisdiction over a nonprofit hospital closely related to a profit-making employer, Duke is the first case to consider the effect of a relationship between a nonprofit hospital and a nonprofit employer over which jurisdiction is routinely asserted. The Board could have justified going either way with a full explanation of its theory. It could have logically reached its decision to dismiss the petition by distinguishing Parkvue and giving controlling weight to the overall nonprofit status of the university. On the other hand, inasmuch as the hospital is closely connected with a non-exempt employer which affects interstate commerce, there is logic also in the conclusion of the dissent-to assert jurisdiction over all Duke University employees, including hospital workers, as being subject to one overall employer, the university. The ultimate decision requiring exemption for Duke Hospital is not nearly as questionable as the Board's failure to articulate the reason for it. ${ }^{122}$ The end result of the Duke University decision, nevertheless, is an implication that a nonprofit hospital operated by a jurisdictional nonprofit employer is exempted from the coverage of the Act. In its more narrow scope, Duke University holds that the above rule applies with certainty to the university-hospital complex. In the absence of needed clarification, other situations, unfortunately, must remain uncertain.

\section{CONCLUSION}

In light of the Board's current policy of extending the Act's coverage to employers engaged in commerce, irrespective of their motives-charitable, educational or otherwise-it is appropriate to reexamine the need for the exemption of hospitals. ${ }^{123}$ At the time the exemption was added, it was generally assumed by the sponsors of the bill that the Board would adhere to a discretionary policy of granting exemptions to nonprofit charitable organizations. ${ }^{124}$ The only likely explanation for the insertion of a hospital exemption is

122. The formula chosen for deciding which employees would not be part of the university unit was based on the percentage of time an employee normally spent in the hospital. Employees who spent more than $50 \%$ of their working time in the hospital were considered employees of the hospital and thus not covered by the Act. 78 L.R.R.M. at 1549.

123. See generally Kochery \& Strauss; Sherman \& Black.

124. See notes 30,45 supra and accompanying text. 
that the American Hospital Association lobbied effectively. ${ }^{125}$ Senator Taft even said that his committee felt it was unnecessary to exempt hospitals specifically, indicating that the need to exempt them was no greater than for any other nonprofit employer. ${ }^{126}$ Thus, when today's Board routinely ignores the nonprofit status of employers and their motives and looks to their impact on commerce, ${ }^{127}$ it is anomalous that hospitals should still be exempt.

None of the reasons which have been advanced from time to time in support of the exemption seem to hold continuing validity, assuming they were ever valid. Most states have not filled the gap by taking jurisdiction over the labor relations problems of charitable hospitals. ${ }^{128}$ Many hospitals easily meet the standards currently set by the Board for determining whether an employer affects interstate commerce. Finally, the argument that hospitals should remain exempt to preserve industrial peace is at best questionable. If the Act achieves its stated purposes-promotion of commercial and industrial stability-hospitals would fare better if made subject to the Board's jurisdiction. ${ }^{29}$

Furthermore, there are several affirmative reasons why the Act should cover nonprofit hospitals which affect commerce. First, it does not seem equitable to force hospital employees to bear the burden of supporting the charitable purposes of the instituions for which they work by accepting a lower standard of living. ${ }^{130}$ Such employees need the ability to bargain for fair wages and desired working conditions as much as any other category of workers. Furthermore, a possible equal protection argument arises on the basis that most nonprofessional hospital service employees are financially poor. ${ }^{131}$ To systematically exclude hospitals from the coverage of the Act is, theoretically, to discriminate against hospital employees as a class, since by far the greatest impact of the exemption falls on them.

The National Labor Relations Board, however, may not extend the coverage of the Act to specifically excluded employers for the

125. See notes 21,24 supra and accompanying text.

126. See note 25 supra and accompanying text.

127. See notes 58-61 supra and accompanying text.

128. See, e.g., St. Vincent's Nursing Home v. Dep't of Labor, 169 N.W.2d 456 (N.D. 1969). But see New York Infirmary, 27 N.Y. S.L.R.B. No. 14, 55 L.R.R.M. 1294 (1964).

129. See NLRA § 1, 29 U.S.C. $\S 151$ (1970); note 53 supra and accompanying text.

130. See Kochery \& Strauss 277; Sherman \& Black 1349.

131. See generally Michelman, Foreword: On Protecting the Poor Through the Fourteenth Amendment, 83 HARV. L. REV. 7 (1969). 
mere purpose of advancing social policy. That is the function of Congress. Whatever the perccived strength of a policy, it must give way when it collides with an unambiguous and specific statutory prohibition. Whether the hospital exemption is so clear and unambiguous as to preclude the possibility of the Board's assertion of jurisdiction over a hospital integrated into a jurisdictional university complex is a qucstion which has now been answered affirmatively by the Board in Duke University. The question of whether the Board will afford the exemption identical treatment in the setting of a nonprofit employer which is not a university remains to be answered. 